\title{
Addressing Challenges of Illicit Cultural Heritage Trafficking in Post-2011 Egypt
}

\author{
Randa Alaa El-Din Fouad \\ Lecturer \\ Tourism Guidance Department and Heritage and Museum Studies \\ Program \\ Faculty of Tourism and Hotel Management \\ Helwan University
}

\begin{abstract}
Egypt is a country renowned for its immense diversity of cultural heritage which has always been struggling with the multivariate impacts of illicit trafficking of artifacts and cultural objects, illegal excavations, pillaging of archaeological sites, and destruction of historical monuments and buildings. The aftermath of the Egyptian revolutions of 2011 and 2013, represented in the political unrest, the unenforceable laws and regulations, the dispersal of the police forces and the lack of governmental funding, has ultimately exacerbated this threat.
\end{abstract}

Despite the exerted governmental efforts in combating illicit trafficking of cultural property on national and international levels, theft, looting, and illegal export remain constant hazards. The major objective of this article is to address the different aspects of the current inherent challenges that impede the implementation of an effective strategy for protecting and safeguarding the Egyptian cultural heritage from illicit trafficking. Moreover, it clarifies the focal key actions for the adoption of safeguarding measures, procedures and standards, while highlighting the necessary precautions needed for achieving the optimal protection for the Egyptian cultural property.

Keywords: illicit trafficking, cultural property, looting, illegal digging, smuggling, challenges.

\section{Introduction}

Cultural property in all its forms constitutes a pivotal and unique testimony of the evolution of the history and identity of different peoples. It is a common asset of humankind that should be preserved in all circumstances and its 


\section{Addressing Challenges of Illicit Cultural Heritage Trafficking in

protection has been promulgated in several international instruments (The UNESCO Courier, 2017).

Throughout the history, cultural heritage and cultural properties have been vulnerable to deliberate vandalism, plunder, and illicit trafficking, particularly during conflict and post-conflict situations in order to demoralize, defeat and eradicate peoples' historical identity and cultural diversity (INTERPOL, 2016: 7).

Recently, organized criminal groups are increasingly involved in the looting and illegal trafficking of cultural heritage through legitimate channels, such as auctions and the Internet, and in lucrative illicit antiquities markets (http://www.unodc.org/unodc/en/organized-crime/intro/emergingcrimes/trafficking-in-cultural-property.html).

Illicit cultural heritage trafficking has always been a transnational hazard, feeding into a black-market trade in antiquities, art, and artifacts. Typically, demand in wealthy countries urges individual in low-economy countries, but have wealth in cultural artifacts, to trade illegaly in antiquities and exceed the internal mandate. Thus, the trafficked objects pass transnationally from the "source" countries to the "market or destination" countries via "transit" countries (Campbell B., 2013: 115). Today, it is noticeable that the black market is receding away from the traditional means of trading towards social media and the internet. Moreover, illicit trafficking in cultural heritage has been identified as a possible source for financing corruption, terrorism and violence (http://www.europeanrights.eu/public/atti/ris_2234 eng.pdf).

The UN Security Council recognized the link between the illicit trafficking of cultural objects and the financing of terrorism with its adoption under Chapter VII of the UN Charter of resolution 2199 in 2015, as well as the devastating impact of cultural heritage destruction in conflict situations with the unanimous adoption of resolution 2347 in 2017

(http://www.unesco.org/new/en/media-services/single-

view/news/our_responsibility to protect cultural heritage from terrori/).

In fact, the world's archaeological heritage is under serious threat as a result of illegal digging and destructive excavations which primarily aim to sell antiquities in the international market. The whole world is suffering from the different aspects of cultural heritage trafficking which eventually result in the loss, destruction, removal or theft of irreplaceable objects. Open borders, political challenges, gaps in the international law and the relevant legislative framework, and the intense use of technology have actively facilitated this kind of illicit trade 
(http://www.unodc.org/unodc/en/organized-crime/intro/emergingcrimes/trafficking-in-cultural-property.html).

A remarkable number of studies have reported that the illicit trade in cultural property would be the third most common form of international criminality after arms and drug trafficking, providing profitable revenue of billions of dollars

(http://www.unesco.org/new/fileadmin/MULTIMEDIA/HQ/CLT/images/63 0X300/Study Prof Renold EN 02.pdf). According to UNESCO, the illicit trafficking of cultural property in the world is valued at $\$ 7$ billion each year and often involved crime groups and criminal (http://www.unesco.org/new/en/culture/themes/illicit-trafficking-ofcultural-property/meetings/forums-seminars-and-informationmeetings/unwto-campaign/).

However, it is difficult to provide an accurate assessment of the global extent of the illicit trade in cultural property since few countries have the motivation to compile periodic statistics of cultural property stolen from museums, galleries, places of worship and private homes, or looted from archaeological sites. Moreover, many crimes remain undetected and the illicit trade of cultural property is mainly fueled by clandestine activities that are secretive by nature

(http://www.unesco.org/new/fileadmin/MULTIMEDIA/HQ/CLT/images/63 0X300/Study_Prof_Renold_EN_02.pdf).

The illicit trafficking of cultural goods or cultural racketeering has been developed across the MENA region following the 2011 Arab Spring uprisings since this type of heritage trafficking usually reaches its highest levels in the areas affected particularly with revolutions, armed conflicts and natural disasters (Paul K., 2016: 21). With regard to Egypt, it is renowned for its affluence in cultural property and archaeological heritage which have always struggled with the hazardous impacts of heritage crimes including illicit antiquities trade and illegal excavations. Trafficking of the Egyptian cultural heritage is not a new phenomenon as it has been recognized since the Pharaonic period and continued to be existing till nowadays.

Pyramids, tombs and other relics have been looted by the Egyptian tomb robbers for centuries. Moreover, substantial heritage features were moved out of Egypt, throughout history, as spoils of war, gifts or specimens for researches that have never been repatriated and today adorning the major museums such as the British Museum and the Louvre Museum (Abungu G., 2016: 240). Additionally, several ancient Egyptian artifacts, obelisks in 


\section{Addressing Challenges of Illicit Cultural Heritage Trafficking in Post-2011 Egypt}

specific, were found standing in the grand and the most famous squares of the UK, US, Turkey and Italy. These obelisks were smuggled between the era of the Roman Empire and the French campaign and remained abroad. For instance, Rome host eight Egyptian obelisks including the Lateranense which dates back to the reign of king Thutmose III (MENA, 2015).

The uprising of the 2011 revolution in Egypt has exacerbated the problem of illicit trafficking of cultural property and looting of antiquities resulted from the unstable political conditions of the country and the absence of law and order at that time. The potential heritage looters are usually not a homogeneous group of offenders. They comprised different segments and identified as the digging poor, locals looking for golden artifacts, local criminals and hoodlums, law enforcement agents, heritage employees, angry mobs and gangs (Teijgeler R., 2013: 232).

Illicit cultural heritage trafficking in Egypt involves several forms ranging from theft of cultural heritage institutions or private collections, through the pillaging of archaeological and heritage sites to the destruction of historical buildings and the displacement of artifacts due to conflicts that undoubtedly cause irreparable damage to the cultural heritage of the country and its nation.

The subsequent illustrates some examples of the different aspects of opportunistic looting, vandalism and illicit trafficking of the Egyptian cultural property since the revolution of 2011 and its aftermath.

\section{(1) - Illicit Digging and Plundering of Archaeological Sites:}

Unsurprisingly, the breakdown in security that followed the collapse of the Egyptian regime after the 2011 revolution onward led to the rampant looting of archaeological sites up and down the country. Moreover, this political disorder has brought lucrative opportunities for illegal diggers searching for hidden treasures and gold. Hundreds of holes were captured by satellite pictures recording serious pillaging in the Pyramid Belt in the desert near Cairo (Heath J., 2015: 183). The latest is the illegal digging that occurred beneath one of the modern houses close to the Giza Plateau which led accidentally to the discovery of a new burial site (Maged. M., 2019).

In addition to the pyramid belt at Giza, other sites were subjected to sporadic looting and illicit digging including Cairo, Alexandria and the North Coast, Beheira, Kafr El-Sheikh, Munufiya, Gharbiya, Daqahliya, Damietta, PortSaid, Sharqiya, Minia, Assiut, Sohag, Luxor and others (Hanna M., 2016:49$50)$. 


\section{(2)- Looting of Museums:}

It seems that the threats of the Egyptian security breakdown did not enclose only to the archaeological sites and the nearby illicit digging but it extended to involve a number of high-profile cases of pillaging and damaging of provincial museums. On 28 January 2011, looters and protesters attacked the Egyptian museum ransacking the gift shop, smashing the display cases, breaking statues into pieces and displacing several objects and artifacts (Sarant L., 2011, https://www.egyptindependent.com/vandals-ravageegyptian-museum-break-mummies/). The severe vandalism of the Egyptian museum resulted in the damage of 70 objects and pillaging of 18 artifacts, some of which were retrieved later (Taylor K., 2011, https://artsbeat.blogs.nytimes.com/2011/02/17/egypts-antiquities-ministersays-valuable-statue-found/).

In September 2013, vandals looted the Malawi National Museum in Upper Egypt, El-Minia governorate, reportedly the worst attack since the Egyptian security breakdown in 2011. The loss was estimated to be 1041 objects, including coins, jewels and statues dating from the beginning of the Egyptian history down to the Islamic period, with 48 artifacts that left burnt and damaged (http://www.unesco.org/new/en/culture/themes/illicit-traffic-of-culturalproperty/emergency-actions/egypt/warning-looting-of-the-malawi-nationalmuseum/).

Some objects at the storerooms of the National Museum of Egyptian Civilization were recorded to be stolen by two officials working at the museum in 2015. The general supervisor of the museum reported the theft of several artifacts and replacing them by replicas including the statue of king Menkaure and a vase dating back to the Mamluk Period (Gubash C., 2015).

\section{(3)- Smuggling of Artifacts:}

Smuggling of antiquities or artifacts is the direct outcome of illicit digging and plundering of museums and archaeological sites. Since 2011, there was a dramatic increase in the scale and organization of smuggling artifacts. The international markets are flooded with several Egyptian objects especially after the 2011 revolution onward. Recent auctions in London, New York, Italy and many other countries exhibited several items from Egypt. The majority of these items were smuggled through the tunnels connecting between Egypt and Gaza and then legally travel to anywhere else. Other objects left the country through air travel as souvenirs or sent to Turkey in order to enter the countries of the European Union (Hanna M., 2016: 54). 


\section{(4)- Destruction of Archaeological and Historical Sites:}

The aftermath of the 2011 revolution is marked with the deliberate attack of angry mobs and Islamists targeting archaeological and historical sites, including mosques and Coptic churches, along the whole country. In 2013, supporters of the ousted Egyptian president Morsi protested inside Al-Fath mosque, at Ramesses Square, causing severe damages to the mosque and its contents. Moreover, the Evangelical Church of Malawi was plundered and burnt by the Islamists, who left the church in ruins (Reilly J., 2013). Additionally, in 2014, a car bomb targeted Cairo Security Directorate causing devastating damage to the Islamic Museum in Cairo and its collections. Several parts of the museum's façade were devastated, the hanging ceiling collapsed and objects of glass and ceramics were badly damaged. Moreover, eight manuscripts were reported to be destroyed at Dar El-Kutub in its vicinity (Fincham D., 2014).

\section{(5)- Illegal Encroachments:}

The revolution of 2011 left many of the archaeological and historical sites and buildings vulnerable to looting, vandalism, land grabbing and illegal encroachments due to the state of lawlessness and the disappearance of the police forces from their spots. Those heritage sites experienced the epidemic casualties of the revolution and the fast-growing population's demand for housing and agricultural lands, which are often grabbed lands belonging to the Ministry of Antiquities (Tassie G. J. et al., 2015: 16). The majority of the grabbed lands were used for building projects and houses, cemeteries as well as agricultural activities. It is noteworthy to mention that the whole land grabbing system strongly adheres to the looting and trafficking of artifacts since the contractors investigate the land searching for valuable items before selling it (Ikram S. and Hanna M., 2013: 35). The Memphite area, Al-Matariya, Alexandria, Fayum, Tell El-Hibeh, Abydos, Upper Egypt, the Eastern Desert and additional areas all over Egypt have been appropriated for cemeteries, expansion of agricultural lands, land grabbers and looters (Ikram S. and Hanna M., 2013: 37).

Despite the exerted governmental efforts aiming to curb the threats of illicit trafficking of cultural heritage property, several inherent challenges are proved to be existing. These challenges might occur as the consequences of the burden placed on local law enforcement, unstable political conditions, institutional failure, lack of training, lack of awareness, remoteness of sites, access to technology, etc., as follows: 


\section{Challenges}

- The illicit trade in cultural goods is international in nature and requires global response and cooperation. Many of the destination countries in the heritage trade ratified the UNESCO 1970 Convention on the Means of Prohibiting and Preventing the Illicit Import, Export and Transfer of Ownership of Cultural Property, and agreed to all of its articles, while others did not or their support did not exceed their signatures on the papers. Despite the efforts exerted by the Egyptian government to repatriate its looted artifacts, Egypt is still struggling to recover its antiquities which are considered as state property. Moreover, many of the auction houses are unwilling to cooperate with requests to delay or cancel sales of items that experts assess have been stolen. Among those who make their money selling antiquities, cooperation with the Egyptian government has been mixed at best. For instance, in June 2019, Christie's auction house in London displayed a catalogue of several ancient Egyptian artifacts for sale, among which is the head of the statue of the famed king Tutankhamen, which was auctioned on 4 July 2019 for more than \$5 million. The Ministries of Antiquities and Foreign Affairs called on Christie's auction house and UNESCO to halt selling the statue and to provide documents proving the statue's ownership. Unfortunately, Christie's auction house ignored the request and kept silent (Magdy S., 2019). Regardless of Egypt's outrage, the auction sold the king's head for almost $\$ 6$ million without sharing information about the buyer. Christie's proclaimed that the sale was legal and valid since the head was in the private collection of the German prince Wilhelm of Thurn and Taxis, and then it was acquired by an Australian dealer in 1973-4. On the other side, Egypt stated that the head was probably stolen in 1970s from El-Karnak Temples, and it will instruct a law firm in the UK to file a civil suit over the sale of the king's head (https://www.bbc.com/news/worldmiddle-east-48922555). In response to this action, Egyptian protesters gathered in front of the auction house holding up placards saying "Egyptian heritage is not for sale" (El-Aref N., http://english.ahram.org.eg/News/337696.aspx).

- The accelerated growth of e-commerce types, particularly business-toconsumer (B2C), as in websites of auction houses, and consumer-to-consumer (C2C), such as eBay and Amazon, facilitated the increase of online sales of illicitly exported or stolen cultural objects. In fact, the majority of the artifacts displayed for sale on the internet do not have authentic documentation and lack their provenance. These artifacts can be tracked and regulated by the authorities responsible for monitoring sales on the internet, however, in many 


\section{Addressing Challenges of Illicit Cultural Heritage Trafficking in Post-2011 Egypt}

cases the objects were sold, due to the rapid nature of e-commerce, before the authorities have the time to investigate their sale (UNESCO, 2018, http://www.unesco.org/new/fileadmin/MULTIMEDIA/HQ/CLT/movable/pdf/ Toolkit 01.pdf).

- Prior to 1983, Egyptian artifacts were legally exported and sold within the protocol of presenting diplomatic gifts by the Egyptian rulers to their counterparts, foreign dignitaries and high officials. Moreover, agreements were formulated permitting foreign archaeological missions to take a percentage of the artifacts they discovered in Egypt. Starting from 1983, law no. 117, amended by Law No. 3 of 2010, was issued banning the selling of antiquities and considered any ancient artifacts found in the country as a state property except for antiquities with ownership or possession that have previously established. Today, many objects have been stolen or illegally excavated and exported in order to be sold by famous auction houses like Christie's, Sotheby's or Bonham. Regrettably, these objects cannot be easily repatriated especially if they have forged documents certifying that they left Egypt before 1970, the date of the UNESCO Convention requiring the repatriation of objects that were illegally trafficked, or if they were exported before the implementation of 1983 law and its amendments (https://www.unodc.org/documents/treaties/organized_crime/Egypt.pdf).

- The ignorance of the effective implementation of the Egyptian bylaws and legislations concerning the obligation of developers to permit archaeological investigation before launching new building activities, in registered archaeological areas, to prevent the occurrence of any deliberate or haphazard archaeological damage (Tassie G. J., 2015: 19).

- The fluctuated economic conditions of the country and the lack of the locals' awareness of the significance of their own cultural property led some to direct their attention to illicit digging searching for hidden treasures. Smuggling of antiquities and their illicit trafficking is a wide lucrative trade for those seeking for profit or instant wealth, without realizing the irreparable damages affecting the cultural heritage property of the country. Moreover, the lack of public visibility for this type of crime compared to other crimes such as drugs or human trafficking can be considered as one of the main challenges of cultural heritage trafficking in Egypt. As proof, a new type of antiquities' robbers appeared during the aftermath of the 2011 and 2013 revolutions. These organized gangs take advantage of the locals' ignorance of the Egyptian bylaws, legislation and penalties and send random messages alleging that they have found precious relics and sought illegal networks to smuggle and sell them. 
- Remote heritage sites and museums are considerably vulnerable to the threat of human neglect and criminal activities that are undertaken for personal gain. The unarmed gangs, who target the buffer zones of the archaeological sites and its surroundings at Dahshur, Saqqara, Lisht and other sites around the country, illegally dig up searching for relevant antiquities to be sold in the black market. The pillaged antiquities are usually shipped abroad and they are either sold through the internet or other illegal channels to fund terrorism indirectly (Pauwels A., 2015).

- The lack of security and adequate protection in some of the heritage sites, regional museums, inadequate inventories and the poor documentation of cultural assets and its legislations can cause an irreversible loss in the country's heritage especially in times of conflicts and troubles.

- The lack of the use of modern technology tools and the well-trained specialist staff can play an indirect role in easing the smuggling of cultural goods. For example, custom inspectors at the airports and ports, who are in charge of preventing the pillaging of artifacts, do not have the proper up-todate X-ray scanners that can detect antiquities as seen in Sohag airport and many other distant ports (Hanna M., 2016).

- Open borders and the absence of the border guards, particularly during times of armed conflicts and political unrest, increasingly facilitated the illicit trafficking of cultural property and pillaging of Egyptian antiquities. For instance, criminals accustomed to conduct smuggling of artifacts across the borders took advantage of the unstable political conditions of the neighboring countries, such as Palestine, Sudan and Libya, which are considered as "transit" countries in the illicit trade of cultural goods. Through the "transit" countries, the illegally trafficked antiquities are eventually exported to the "market or destination" countries (Hanna M., 2016: 49-50).

\section{Key Actions and Recommendations}

- More cooperation is needed between the Egyptian government and foreign governments concerning the prevention of the export of the Egyptian artifacts and laws regulating the repatriation of the illegally trafficked cultural objects that are already displayed in auction houses. In response to such issues, UNIDROIT (International Institute for the Unification of Private Law) elaborated hard and soft international tools aiming to regulate suitable measures for the art market. Additionally, the international cooperation in the field of cultural heritage protection is strengthened with the launch of the Academic Project (UCAP) which brings together governmental 


\section{Addressing Challenges of Illicit Cultural Heritage Trafficking in Post-2011 Egypt}

organizations, universities, scholars, law enforcement agencies and practicing lawyers in a trans-academic network through the UNIDROT's partnerships with UNESCO, INTERPOL, UNODC (United Nations Office on Drugs and Crime), WCO (World Customs Organization), ICCROM (International Center for the Study of the Preservation and Restoration of Cultural Property), ICOMOS (International Council on Monuments and Sites), ICOM (International Councils of Museums), other NGOs and national police forces (https://www.unidroit.org/cultural-property). Accordingly, the Egyptian government should get involved in such initiatives and benefit from the framed international movements and agreements.

Moreover, Egyptian ambassadors abroad can play a pivotal role in the restitution of the illicitly trafficked cultural property by providing a legal framework for negotiation and dispute settlement.

- Global innovative collaboration is required between the Egyptian police forces, tourism sector, local community and the relevant international and regional agencies such as ANCBS (Association of National Committees of the Blue Shield), ICOM, ICOMOS, ICCROM, WCO, UNODC, INTERPOL and UNESCO in order to protect cultural heritage from looting and address the best practices and measures to combat the problem of illicit trafficking of cultural property.

- Firm legal preventive measures and safeguarding standards should be implemented regarding the right to control the sale of the Egyptian antiquities abroad. Laws and regulations should be formulated to achieve a better deep web monitoring of the online displayed Egyptian artifacts.

- With regard to land grabbing and illegal encroachments, archaeological investigations and assessments are needed prior to initiating any building activities or developments in registered historical or archaeological areas through the effective implementation of firm legislation and bylaws. Moreover, the evaluation works of the developers who undertake these building projects should be monitored and conducted as a part of an Environmental Impact Assessment (EIA), in consonance with 1968 UNESCO Recommendations Concerning Preservation of Cultural Property Endangered by Public or Private Work (http://portal.unesco.org/en/ev.phpURL_ID=13085\&URL_DO=DO_TOPIC\&URL_SECTION=201.html).

- The necessity of introducing training modules on illicit cultural heritage trafficking in school and university curricula to raise the students' awareness of the threats of losing their cultural heritage identity and engage 
them in the fight against illicit trafficking of cultural heritage. Besides, links should be developed between school students from one side and museums and heritage sites from another side to create educational and entertaining programs permitting them to gain knowledge about their cultural heritage and how to protect it from looting, vandalism, pillaging and smuggling. Field schools are also needed for teaching modern archaeological practices and establishing more exchange programs between universities in order to elevate technical skill levels and create new theoretical and scientific approaches (Tassie G. et al., 2015: 40).

- The World Heritage Day, $18^{\text {th }}$ of April, is an international observance that is celebrated in Egypt every year at the UNESCO Cairo office in collaboration with the Ministry of Antiquities, the Ministry of Culture, the National Organization for Urban Harmony (NOUH) and the Cairo Governorate. Primarily, it aims to promote awareness about the diversity of cultural heritage of humanity and the efforts required for their protection and conservation. The celebration usually includes workshops, art exhibitions, dialogue sessions, interactive experiences and concerts. The proceedings of this day should be linked with the current situation in regard to illicit trafficking of cultural heritage property. A series of awareness-raising campaigns should be launched among the locals about the importance of collectively protecting cultural heritage and sensitize on the negative impacts of looting and pillaging cultural antiquities.

- The UNESCO's initiative regarding the launch of a series of awareness-raising video clips campaign targeting tourists visiting different regions of the world should be effectively implemented in Egypt. The main objective of this campaign is to warn the tourists about the cultural objects they purchase and to ensure that they have the authorization documents to export the objects out of the country. These clips are supposed to be disseminated by the government on the internet, social media, hotels, cultural sites, tourists' offices and travel hubs (airports, train stations, ports, etc.). Each clip is illustrated with the following text(http://www.unesco.org/new/en/culture/themes/illicit-trafficking-of-culturalproperty/videos/heritage-is-identity-dont-steal-it/): 


\begin{abstract}
"Dear tourist, make sure that the souvenir you take home hasn't been looted from a museum or illegally excavated from an archeological site. Please check its provenance and verify that it can be exported out of the country! Keep in mind that a cultural object is not a simple merchandise: it embodies history and has a symbolic value for the local people. Help stop illicit trafficking!".
\end{abstract}

- The movement of the trafficked cultural objects is mainly facilitated by corrupted officials. Hence, corruption is considered a major obstacle in detecting and preventing cultural heritage smuggling offenses. Moreover, it impedes national and international law enforcement to fight against the illicit trafficking of cultural heritage property. Various measures should be adopted to curb, reveal and penalize related corruption of public officials.

This correspondingly leads to a further future direction towards capacity building at diverse levels of law enforcement in the measures that might be taken to identify, investigate and prosecute those involved in the illicit trafficking of cultural artifacts.

- With a view to protecting the Egyptian cultural heritage from being illicitly trafficked across the borders, an effective partnership and cooperation between Egypt and the relevant international and regional organizations such as UNESCO, ICOM, WCO, INTERPOL and UNODC are needed to provide customs' officers with a wide and flexible range of activities. In this regard, capacity building workshops and training programs should be held to increase the preventive measures recommended by the 1970 UNESCO Convention on the Means of Prohibiting and Preventing the Illicit Import, Export and Transfer of Ownership of Cultural Property to combat all aspects of smuggling of cultural heritage goods.

- Heritage and museums' experts, customs and police officers, researchers and academics should participate in the regional and international conferences, training courses and sessions, workshops, etc., to discuss the feasible practices and actions required for the prevention of offenses related to the illicit trafficking of cultural heritage such as the latest conference held in Munich, Germany May 2019 (https://germancooperation.rs/regionalconference-on-combatting-trafficking-of-cultural-heritage/).

Moreover, bringing together experts from various fields to discuss one core issue maintains momentum on cultural heritage protection and creates an ad 
hoc coordination system to fight the pillaging and plundering of cultural property not only in Egypt but in most of the MENA region countries.

\section{Conclusions}

Undoubtedly, the illicit trafficking of cultural property is a serious crime that forms a threat to security, identity of nations and diversity of cultural expressions. It is evident that this kind of trafficking is sometimes linked to financing organized crime, corruption networks, money laundering or even terrorism in conflict areas. Egypt is considered to be among the MENA region countries that experienced the transnational aspects and hazards of illicit trafficking of cultural artifacts on a much broader scale than ever before especially during the revolutions of 2011 and 2013 and their aftermath.

For this purpose, combating the destruction of cultural heritage and illicit trafficking of cultural property and preventing its smuggling has been remaining as one of the crucial issues discussed by the Egyptian government.

In this regard, the development of law enforcement and judicial cooperation can play an essential role in fighting against all forms of cultural heritage trafficking. Besides, the adoption of a number of preventives measures and safeguarding standards could contribute to tackling the inherent challenges of the illicit trafficking of cultural property. National and international collaboration, attempts and calls in the field of cultural heritage protection are needed likewise to address the problem of plunder, theft, illegal trade, destruction of cultural heritage in Egypt.

Moreover, it is necessary to sensitize the public, particularly the younger generations, about the significance of their cultural heritage and the jeopardy associated with illicit trafficking, looting and pillaging of cultural antiquities.

\section{List of References}

-Abungu G. (2016). Illicit Trafficking and Destruction of Cultural Property in Africa: A Continent at a Crossroads. In: Charney N. (ed.) Art Crime: Terrorist, Tomb Raiders, Forgers and Thieves. New York: Palgrave Macmillan, pp. 240-254.

-Campbell B. P. (2013). The Illicit Antiquities Trade as a Transitional Criminal Network: Characterizing and Anticipating of Cultural Heritage. International Journal of Cultural Property, 20 (2), pp. 113-153. 


\section{Addressing Challenges of Illicit Cultural Heritage Trafficking in Post-2011 Egypt}

-Hanna M. (2016). Documenting Looting Activities in post-2011 Egypt. In Desmarais F. (ed.) Counting Illicit Traffic in Cultural Goods. The Global Challenge of Protecting the World's Heritage. Paris: ICOM, pp. 47-63.

-Heath J. (2015). Archaeology Hotspot Egypt: Unearthing the Past for Armchair Archaeologists. Maryland: Rowman \& Littlefield.

-Paul K. A. (2016). Cultural Racketeering in Egypt-Predicting Patterns in Illicit Activity: Quantitative Tools of the $21^{\text {st }}$ - Century Archaeologist. In Chalikias K., Beeler M., Pearce A. and Ranette S. (eds.) The Future of the Past: From Amphipolis to Mosul, New Approaches to Cultural Heritage Preservation in the Eastern Mediterranean. Boston: Archaeological Institute of America, pp. 21-30.

-Pauwels A. (2015). Isis and Illicit Trafficking in Cultural Property: Funding Terrorism through Art. Italy. Freedom From Fear Magazine, United Nations Interregional Crime and Justice Research Institute, Nov. 1, 2015, viewed 5 June 2019, < http://f3magazine.unicri.it/?p=1098>.

-Salima I. and Hanna M. (2013). Looting and Land Grabbing: The Current Situation in Egypt. Bulletin of the American Research Center in Egypt (BARCE), 202, Cairo, pp. 33-47.

-Tassie G. J., De Trafford A. and Van Wetering J. (2015). Egypt's Heritage in Times of Conflict and Crises. In Hassan F. A. et al. (eds.) The Management of Egypt's Cultural Heritage. London: Golden House Publications, pp. 14-47.

-Teijgeler R. (2013). Politics and Heritage in Egypt: One and a Half Years after the Lotus Revolution. Journal of the World Archaeological Congress (JWAC), 9, New York, pp. 230-251.

\section{Websites}

-BBC News 2019, Egypt to Sue Christie's to Retrieve $£ 4.7 \mathrm{~m}$ Tutankhamun Bust, viewed 10 September 2019, <https://www.bbc.com/news/worldmiddle-east-48922555>.

-Council of Europe 2018, Deliberate Destruction and Illegal Trafficking of Cultural Heritage, viewed 9 February 2019, $\leq$ http://www.europeanrights.eu/public/atti/ris 2234 eng.pdf $>$.

-El-Aref, N 2019, Egypt: Stopping Trade in Our Monuments, viewed 10 September 2019, <http://english.ahram.org.eg/News/337696.aspx $>$. 
-Fincham, D 2014, Explosion at the Islamic Art Museum in Cairo, viewed 2 May 2019, <http://illicitculturalproperty.com/explosion-at-the-islamic-artmuseum-in-cairo/>.

_German Cooperation 2019, Regional Conference on Combating Trafficking of Cultural Heritage, viewed 10 July 2019,

$<$ https://germancooperation.rs/regional-conference-on-combatting-

trafficking-of-cultural-heritage/ $>$.

-Gubash, C 2015, Egypt Museum Curators Accused of Replacing Antiquities with Fakes, viewed 2 May 2019

$<\underline{\text { https://www.nbcnews.com/news/world/egypt-museum-curators-accused- }}$ replacing-antiquities-fakes-n369776 $>$.

-INTERPOL, Protecting Cultural Heritage, viewed 20 May 2019, $<$ https://www.interpol.int/en/Crimes/Cultural-heritage-crime/Protectingcultural-heritage $>$.

-Joint European Commission-UNESCO Project 2018, The Legal and illegal Trade in Cultural Property to and throughout Europe: Facts, Findings and Legal Analysis, viewed 7 April 2019,

$<$ http://www.unesco.org/new/fileadmin/MULTIMEDIA/HQ/CLT/images/63 0X300/Study_Prof_Renold_EN_02.pdf $>$.

-Maged, M 2019, Illegal Excavation Near Giza Accidently Uncovers Ancient Tomb, viewed 8 May 2019,

$<\underline{\text { https://ww.egyptindependent.com/illegal-excavation-near-giza-accidentally- }}$ uncovers-ancient-tomb/>.

-MENA, 2015, Musuem Official: 15 Stolen Obelisks Abroad, viewed 25 December 2019, <https://ww.egyptindependent.com/museum-official-15stolen-obelisks-abroad/>.

-Reilly, J 2013, Looters Ransacked Egyptian Antiquities Museum and Snatch Priceless Artefacts as Police Move Inside Stormed Cairo Mosque, viewed 16 May 2019, <https://www.dailymail.co.uk/news/article-2396100/EgyptLooters-ransack-Egyptian-antiques-museum-snatch-priceless-artefacts.html $>$.

-Sarant, L 2011, Vandals Ravage Egyptian Museum, Break Mummies, viewed 23 April 2019, < https://www.egyptindependent.com/vandals-ravageegyptian-museum-break- mummies/ $>$. 
-Taylor, C 2019, Ancient Egyptian Artefact Returned after Being Smuggled to London Auction House, viewed 27 June 2019, $<$ https://www.cnbc.com/2019/01/09/ancient-egyptian-artefact-returned-afterbeing-smuggled-to-london.html $>$.

-The UNESCO Courier 2017, A Historic Resolution to Protect Cultural Heritage, viewed 9 February 2019, <https:/en.unesco.org/courier/2017october-december/historic-resolution-protect-cultural-heritage $>$.

-UN 2016, Protecting Cultural Heritage: An Imperative for Humanity, viewed 20 May 2019,

$<\underline{\text { http://www.unesco.se/wp-content/uploads/2016/09/2016-Protecting- }}$ cultural-heritage.-An-imperative....pdf $>$.

-UNESCO 2013, Warning: Looting of the Mallawi National Museum in the Upper Egypt City of Minia, viewed 23 April 2019, $<$ http://www.unesco.org/new/en/culture/themes/illicit-traffic-of-culturalproperty/emergency-actions/egypt/warning-looting-of-the-mallawi-nationalmuseum/>.

-UNESCO 2014, Illicit Trafficking of Cultural Property, viewed 7 April 2019 2 <http://www.unesco.org/new/en/culture/themes/illicit-trafficking-ofcultural-property/meetings/forums-seminars-and-information-

meetings/unwto-campaign/>.

-UNESCO 2017, Heritage is Identity, Don't Steal it!, viewed 5 July 2019, $<$ http://www.unesco.org/new/en/culture/themes/illicit-trafficking-of-culturalproperty/videos/heritage-is-identity-dont-steal-it/>.

-UNESCO 2017, Our Responsibility to Protect Cultural Heritage From Terrorism and Mass Atrocities, viewed 9 February 2019, $<$ http://www.unesco.org/new/en/media-services/singleview/news/our_responsibility to protect_cultural heritage from terrori/>.

-UNESCO 2018, Fighting the Illicit Trafficking of Cultural Property, viewed 29 June 2019 , $<$ http://www.unesco.org/new/fileadmin/MULTIMEDIA/HQ/CLT/movable/p df/Toolkit_01.pdf $>$.

-UNESCO Constitution 1968, Recommendation concerning the Preservation of Cultural Property Endangered by Public or Private Works, viewed 5 July 2019 , 
$<$ http://portal.unesco.org/en/ev.php-

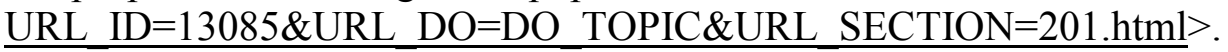

-UNIDROIT, UNIDROIT Work and Instruments in the Area of Cultural Property, viewed 17 September 2019, <https://www.unidroit.org/culturalproperty>.

-UNODC, Trafficking in Cultural Property: Stealing from the Past is Destroying the Future, viewed 12 February 2019, $<$ http://www.unodc.org/unode/en/organized-crime/intro/emergingcrimes/trafficking-in-cultural-property.html $>$.

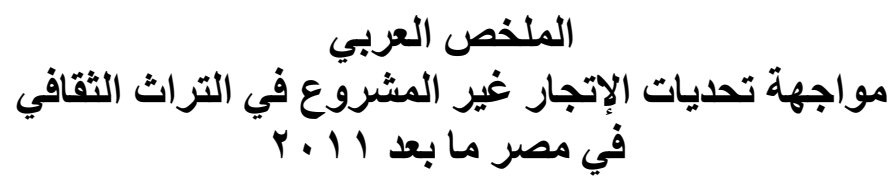

تُعرف مصر بشهرتها الواسعة في التنوع الهائل للتراث الثقافي والذي كان طالما بعاني من الأثار

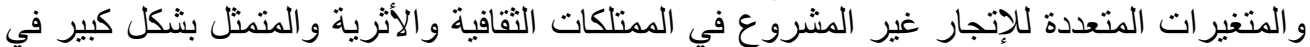

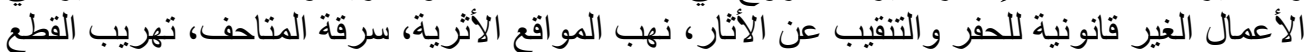

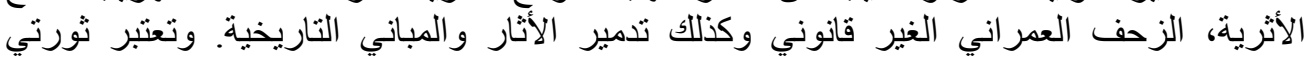

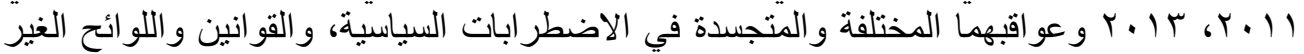

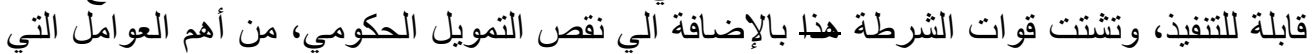
ساهمت في تطور وتفاقم هذا التهديد بشكل ملحوظ.

و على الرغم من الجهود الحكومية المبذولة لمكافحة سُبل الإتجار غير المشروع في الممتلكات الثقافية

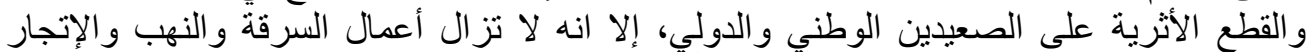

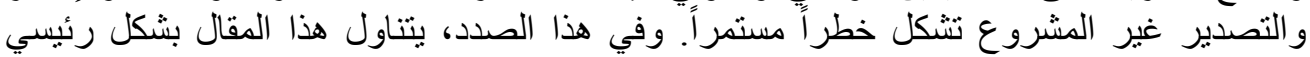

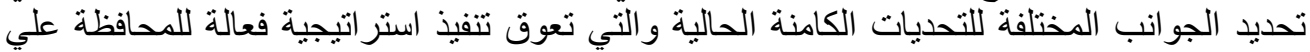

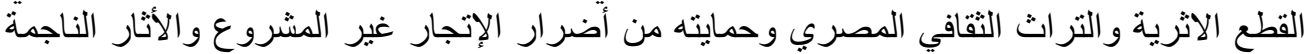

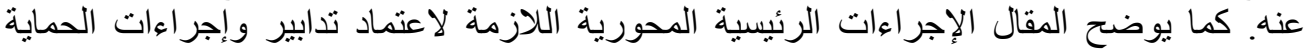

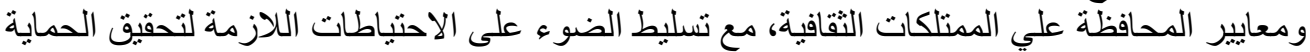
المنلى للقطع الاثرية والممتلكات الثقافية المصرية. 